\title{
Fostering Students' Appreciating Ability through Analyzing the Metaphors in a Short Story
}

\author{
Shaojun Duan* \\ School of Foreign Languages \\ Kunming University \\ Kunming, China \\ duanshaojun2709@126.com
}

\begin{abstract}
Max Shulman is a 20th century American writer, best known for his short stories. His writing style is always humorous. Hence most of studies on "Love is a Fallacy" in academic world mainly concentrate on his writing style and analys is of features of characters. In fact, this short novel entails rich rhetoric devices, among which the metaphor adds much color to this work, making readers easier to understand it. Therefore, this paper tries to put forward an example by analyzing three types of metaphors in this novel in order to help students master and appreciate it better in American literature teaching so as to foster their appreciating ability.
\end{abstract}

Keywords-American literature teaching; appreciating ability; love is a fallacy; metaphors

\section{INTRODUCTION}

Traditionally, metaphor is often regarded as only a figure of speech. In the view of rhetorical speech, the difference between metaphor and simile is that the metaphor compares two objects without using words "like" or "as". However, with the rising of philosophy, linguistics, psychology and other sciences, metaphor does not confine the field of rhetorical speech, and "it is not enough to study metaphor as a figure of speech or language phenomenon" [1]. It has become a way of human thinking, which is to understand and experience one "domain through another" [2]33, of which via the association or resemblance between two objects. According to the existence form, metaphor is divided into three types: lexical metaphor, conceptual metaphor and grammatical metaphor. Max Shulman is a 20th century American writer, best known for his short stories. His writing style is always humorous. Hence most of studies on "Love is a Fallacy" in academic world mainly concentrate on his writing style and analysis of features of characters. In fact, this short novel entails rich rhetoric devices, among which the metaphor adds much color to this work, making readers easier to understand it. Therefore, this paper tries to put forward an example by analyzing three types of metaphors in this novel in order to help students master and appreciate it better in American literature teaching so as to foster their appreciating ability.

\section{LEXICAL METAPHOR}

"Word is the minimal meaningful language unit which can be used alone" [3]57. That is one of the functions of word is to express meaning. Its form has nothing with its meaning. So when the form of word does not change, it's meaning just change. However, lexical metaphor is rightly produces because of the similarities between two words which represent two objects. Namely, these two objects have similarities in meaning or something like that. Noun, verb, adjective and adverb in English language really contribute in forming one sentence and expressing meaning of sentence. Thus, lexical metaphor is split into nominal metaphor, verbal metaphor, adjectival metaphor and adverbial metaphor. In "Love is a Fallacy", these four types of metaphor are present in it.

\section{A. Nominal metaphor}

Nominal metaphor refers to that the metaphor of one sentence or paragraph is shown by a noun or noun phrase. It is known that noun has referential function, which is easier to recognize and understand the similarity or connection between two domains. Besides, noun is usually a thing, person, place or object. Yet these things are imaginable. Thus, it is convenient to communicate when people use nouns or noun phrases to metaphor. For example:

I was not Pygmalion; I was Frankenstein.[4]73

In this sentence, two nouns "Pygmalion" and "Frankenstein" are metaphors. The author sees himself as Pygmalion when he is engaged in dating with Polly. The similarity between Pygmalion and author is that they both put their hearts into their loved person. But when the author fails to develop further with Polly, he becomes Frankenstein. The similarity between Frankenstein and the author is that they make soulless monster by their own. Here, the author makes Polly, who refutes the author by using learned logic.

\section{B. Verbal metaphor}

For verbal metaphor, that is to say, the verbs or verbal phrases in the sentence and subjects or objects results in metaphor. For example:

He didn't have it exactly, but at least he had first rights on it. I refer to his girl, Polly Espy. [4]63 
In above sentence, verbal metaphor is produced by the verb "have" and "Polly Espy". Usually, the word "have" matches with things, which is lifeless. But here it maps into a person "Polly Espy". The author shows his disrespect towards Polly Espy by using metaphor.

\section{Adjectival metaphor}

Adjective is often used to describe a noun or noun phrase. Therefore, adjectival metaphor is caused by the conflict between adjective and noun or noun phrase. For example: [4]63

My brain, that precision instrument, slipped into high gear.

In this sentence, "my brain” and "precision instrument” and "high gear" form the metaphor. The author thinks his brain is like an instrument which is accurate and precision, which shows his cleverness and astuteness. At the same time, by using this metaphor, it is not hard to see that Polly is a foolish girl, who is far away from the author. Moreover, "my brain" maps into "high gear". He sees his mind as a machine that has gears. This metaphor reveals the similarities between his mind and machine. In this metaphor, "precision" and "high" reveal that his brain is a machine running at high speed, operating accurately and quickly.

\section{Adverbial metaphor}

In English language, adverb is usually applied to modify adjective or verb. Therefore, for adverbial metaphor is formed by adverbs and modifiers. Generally, when using a word to modify another, these two objects must be affiliated. In other words, two domains must have the systematic set of correspondence between them. Exactly, that is the working mechanism of metaphor. While, adverbial metaphor also suggests the similar relationship between adverbs and its modifiers. For example:

\section{I stroked my chin thoughtfully. [4]63}

Essentially, "thoughtfully" means in a thoughtful manner or showing considerations and thoughtfulness. "Stroked" means the act of swing or striking. It should match these words "tenderly", "heavily". Here, "thoughtfully" matches verb "stroked", which causes the metaphor. So this sentence can be understood like this: I stroked my chin like thinking something deeply. Compared with above four types lexical metaphor, it's obvious that adverbial metaphor is weaker than the other three metaphors.

\section{CONCEPTUAL METAPHOR}

Conceptual metaphor is built on the cognitive ability. It is produced by the connection between two domains and shown by the conceptualization. Lakoff have ever mentioned in his work Metaphor We Live By: (1) conceptual metaphor is not direct expression of speech. It is an internal process in language. (2) Conceptual metaphor is summarized through daily expression. (3) Conceptual metaphor possesses the ability of "generating".

The development and depth of human logical thinking, to some extent, depend on metaphor, because human logical thinking is always from near to far, from shallow to deep and from abstract to concrete. However, in this process, metaphor is accompanied with human logical thinking, which hits the mark of knowing and explaining things. And human beings have known some domains throughout constant evolution, such as "up and down", "inside and outside" and so on. At the same time, people use the domain from drawing metaphorical expressions to understand the target domain which is trying to know. Thus this process, metaphorically logical thinking results in some systematical and conceptual metaphors. On the contrary, these metaphors influence human logical thinking. So people often use certain metaphors to express their ideas or thoughts and make a conversation, in which they have formed the conceptual metaphor in their mind. For example:

Love is a fallacy. [4]61

In this sentence, the conceptual metaphor "love is a fallacy" generates the following understandings about it:

Love cannot be deduced from a set of given premises.

Love cannot follow the given rules.

Love is an error, a deception and an emotion that does not follow the principles of logic.

Above italic words are ones that are related to the fallacy. "Fallacy" means a false argument. Usually, an argument is true (deductively valid) if the premises can provide enough conclusive evidence for the conclusion. Otherwise the argument is wrong. It is said to be a fallacy. As time goes by, these italics are used to describe "love". Although this conceptual metaphor "love is a fallacy" does not show in above three sentences, the italic words are really confined by it. When people talk or write, they are always accustomed to choosing proper words to express their thoughts. However, they have adopted conceptual metaphor unconsciously.

Actually, "love" and "fallacy" are distinct domains. But here the author associates them. This connection is not arbitrary but close to the plot of this passage: Dobie Gills, a self-conceited freshman in a school struggles against Petey Burch, his stupid roommate whose girlfriend he plans to steal and Polly Espy, the beautiful dumb girl he intends to marry after reeducation. Finally, Dobie Gills is backfired by Polly Espy due to his self-conceit. Thus, love develops with what it is in people's eyes. "Love" and "fallacy" are two similar things. "Fallacy" is causes if the premises cannot provide enough conclusive evidence for the conclusion. So does love. If any one of two people in love lies to the other or not be loyal, then the ending of them is just the separation. This becomes a mistake from the moment when they are together.

\section{GRAMMATICAL METAPHOR}

"Grammar is the realization of the real world" [2]34. Grammatical metaphor is the metaphor which associates real objects in life with the realization of words. Namely, grammatical metaphor emphasizes the relationship between the forms of grammar and the meaning of the words. On the condition of the correspondence between form and meaning, the similarities of two objects can form. Halliday has ever put forward that grammatical metaphor can be divided into conceptual grammatical metaphor and interpersonal 
grammatical metaphor. In fact, grammatical metaphor can be also split into the following two kinds, which appears in the story Love is a Fallacy.

\section{A. Metaphor by grammatical terms}

For example: He didn't have it exactly, but at least he had first rights on it, I refer to his girl, Polly Espy. [4]63

In this sentence, the word "it" is usually used to refer to an animal or a thing that has no life. Here, it refers to a person who is Polly Espy. In other words, Polly Espy is regarded as an animal. In Dobie's eyes, Polly is just something. By using grammatical metaphor, we can see that Dills has disrespect towards Polly Espy. He purely sees Polly as a thing which will be improved by his intellect.

\section{B. Metaphor by grammatical forms}

For example: With one omission, Polly fitted these specifications perfectly. [4]64

In the grammatical metaphor, the realization of nouns is the typical form. In above example, "specification" is the realization form of adjective "specific". Initially, "specification" has nothing to do with a person. It is used to refer to an instruction of one commodity. Here, "specification" is the object of verb "fitted". Accurately, it is the receptor of the action. Throughout the process of change between two objects, it leads to grammatical metaphor.

\section{EFFECTS OF METAPHORS IN "LOVE IS A FALLACY”}

\section{A. Lucid and vivid}

The outstanding characteristic of metaphor is conciseness and vividness. Generally, just one word or phrase in written or spoken language can convey people's emotion, such as love, hatred, beauty, ugliness and so on. For example:

\section{Love is a fallacy. [4]61}

This sentence is a short one, which uses metaphor. Originally, "love" and "fallacy" are distinct from each other. They demonstrate different meaning. Here, the author connects "love" with "fallacy", because there are some resemblances between them. Some qualities of "love" are like "fallacy". In fact, "love" is a kind of emotion. "Love" and "emotion" belong to the same semantic field. "Love" is the hyponymy of "emotion" and has some features of emotion. "Love" is regarded as "fallacy", because the author holds that "love" does not follow the rules of logic. By using one word "fallacy", it reveals author's suspicious attitude toward love vividly and briefly. At the same time, the readers can make reactions to the author's thoughts of love.

\section{B. Novel and humorous}

I.A. Richard said, "All language is vitally metaphorical”.

[5]4 So when language is used to talk about things, it will produce the novelty and present its charming features. Meanwhile, in daily communication, speakers always lie to hear some nice words rather than some stereotyped ones. What's more, in order to emphasize features of things and extrude the information that they want to express, people often apply metaphor to their discourse. For example:

Maybe somewhere in the extinct crater of here mind a few members still smoldered. Maybe somehow I could fan them into flame. [4]70

In this sentence, the word "crater" initially refers to a very large hole in the ground, which has been caused by something hitting it or by an explosion. Here, the author compares "crater" with Polly's mind, which makes readers think of volcano. The word "smoldered" not only matches with "crater" but also describes the state of Polly's mind. By using this metaphor, on one hand, the author shows the mind of Polly to readers; on the other hand, these words add humorous effect to sentence with its metaphorical features.

\section{Euphemistic and elegant}

As Advanced Learner's English-Chinese Dictionary points out, metaphor is a word or phrase used in an imaginative way to describe something or somebody else, in order to show that the two things have the same qualities and to make the description more powerful. Therefore, when a sentence appears to be metaphorical, this sentence usually expresses meaning indirectly. For example:

In other words, if you were out of the picture, the field would be open.[4]65

In this sentence, the author sees Petey and Polly as actor and actress. The love between Petey and Polly is just like a play. If any one of them is out of the stage, that is to say, out of their love, others will achieve the opportunity to talk love with Polly or Petey. In this sentence, the author does not use "didn't talk love with Polly" and "chance", however, he uses "out of the picture" and "the field would be open". By using this metaphor, the author shows his mind or ideas euphemistically and indirectly, he also keeps a harmonious relationship with his roommate. Therefore, metaphor mixes politeness with smooth of written or spoken language.

\section{Filling in the gap between words}

The most obvious characteristic in form of metaphor is that changing from "to be as" to "to be". It is this change that makes English be a special language. And metaphor also shows development and alertness of English. When people are talking in English, they seem to be that they can't find a proper word to express what they want to say. At this time, metaphor plays a key role in communication. On one hand, metaphor makes conversation go smoothly; on the other hand, it fills in the language gap due to lacking of right words. For example:

With Lakoff have ever mentioned in his work Metaphor one omission, Polly fitted these specifications perfectly. [4]64

In above example, the literal meaning of "specification" refers to a detailed description of design criteria for a piece of work, which is an introduction of a commodity. However, in this sentence, author compares Polly to goods, which is not a perfect one and needs to be improved to serve people better. By using this metaphor, author finds the word "specification" to 
match with Polly, which expresses his ideas or thoughts about Polly.

\section{CONCLUSION}

When we happen to encounter one sentence in one text, we just figure out that it applies the metaphor but not analyze which metaphor it belongs to or which function it has in the sentence or its role in the context, which leads to our difficult understanding of the meaning of one sentence. As a result, we can't master or appreciate one passage well. Max Shulman is a giant in American literature. He is famous for his short stories, among which "Love is a Fallacy" stands out in a remarkable place, which is a worthwhile short novel to study and also attracts great attention in academic world. This paper presents an analysis of types of metaphor in "Love is a Fallacy": lexical metaphor, conceptual metaphor and grammatical metaphor. By analyzing like this, we can see that metaphor is really a wide range, it does not confine in the field of rhetoric. It is not only a rhetorical device but also a way of helping us to understand certain abstract objects by linking up the similarities between two domains. Through analyzing the different types of metaphors in "Love is a Fallacy", we can help students appreciate this short novel in a better profound level, as a result fostering their appreciating ability.

\section{REFERENCES}

[1] Z. Yuliang. “An Analysis of Love Metaphor Love Is A Journey from the Perspective of Cognition," in Domestic and Foreign Literature Research, vol. VIII, Z. Wen, Eds. Hefei: Overseas English, 2011, pp.364-365.

[2] E. Sweetser. From Ety mology to Pragmatics: Metaphorical and Cultural Aspects of Semantic Structure. Beijing: Peking University Press, 2002.

[3] H. Zhuanglin. Linguistics. Beijing: Peking University Press, 2011.

[4] Z. Hanxi, W. Lili. Advanced English (Book II). Beijing: Foreign Language Teaching and Research Press, 2010.(In Chinese)

[5] M. Rakova. The Extent of the Literal: Metaphor, Polysemy and Theories of Concepts. Beijing: Peking University Press, 2004. 